\title{
Basic Research on BIM-Based Ouantity Take-off Guidelines
}

\section{Seokheon Yun and Sangchul Kim}

Dept. of Architectural Engineering, Engineering Research Institute, GyeongSang National University, Jinju, South Korea Dept. of Architectural Engineering, Hanbat National University, Daejeon, South Korea

http://dx.doi.org/10.5659/AIKAR.2013.15.2.103

\begin{abstract}
Various types of building information should be linked to 3D model objects for their effective use by stakeholders. Because Building Information Modeling (BIM) based on 3D is used by different stakeholders, the created BIM need standard guidelines for each purpose, as, for example, for quantity take-off. Thus, this study was conducted to propose guidelines for BIM modeling for quantity takeoff in the framework, especially, in the concrete and form. The proposed guidelines adopted each element of the BIM model based on an analysis of the problem of the general BIM model. Moreover, the usability and accuracy of the reinforced structure modeling guidelines were verified by comparing the quantity of the commercial estimation software and the modeling quantity using the proposed modeling guidelines.
\end{abstract}

Keywords: BIM, Quantity Take-off, Modeling

\section{INTRODUCTION}

The construction industry is quickly shifting from 2D CAD to 3D CAD use and into the Building Information Modeling (BIM) environment during its life cycle. BIM could be called the driving force of the next-generation construction, and the future could be called a BIM era using 3D.

Although BIM is generally thought of as a model, its important element, for its practical use, is its information. Various types of information should be connected to this $3 \mathrm{D}$ model so that such information can be effectively used by many people participating in the construction.

Accordingly, this study was conducted to present BIM guidelines for the active use of modeling data and quantity data through effective and accurate modeling in terms of automatic quantity take-off using BIM.

This study focuses on the framework (especially, the reinforced concrete structure) that is the most basic of the many processes performed in construction work, and ArchiCAD, among the many BIM tools.

The problem caused by BIM modeling is analyzed herein after the

Corresponding Author: Seokheon Yun, Associate Professor

Dept. of Architectural Engineering, Engineering Research Institute,

GyeongSang National University, Jinju, Korea

900 Gajwa-Dong Jinju Gyeongnam 660-701 Korea

Tel:+82 557721755 e-mail: gfyun@gsnu.ac.kr

This study was partly supported by NRF under Grant No. 2011-001585.

This is an Open Access article distributed under the terms of the Creative Commons Attribution Non-Commercial License (http://creativecommons. org/licenses/by-nc/3.0/) which permits unrestricted non-commercial use, distribution, and reproduction in any medium, provided the original work is properly cited. quantity take-off via general BIM modeling is compared with that performed by a quantity surveyor using commercial estimation software, starting with a literature review. A virtual project is targeted. Then BIM modeling guidelines are presented by element after the framework is disintegrated. The effect of the guidelines are verified by comparing the quantity extracted through the BIM modeling created from the proposed guidelines with the quantity determined using commercial estimation software.

\section{LITERATURE REVIEW}

1) BIM Definition and Tools

a) BIM Definition

BIM computerizes the materials and construction information related to the construction process. It is an essential elemental technology for keeping pace with international trends or for consolidating a country's international competitiveness. It can be called a parametric-based integrated management system or technique that can conveniently use all the information created during the life cycle of a building in each stage, using a 3D model built up with such information (Lee, 2010 and Gu et al., 2010).

BIM is also called Virtual Construction and Digital Project Management, among others (Choi, 2008). Table 1 shows the definitions of BIM in different organizations.

BIM has two important advantages: it can offer graphic components and information management circumstances.

It is based on digital documents in the design and all other phases of building construction, and can create quantity, cost, schedule, material, and structure information through centralization.

Therefore, it can facilitate precise decision-making. It can also share all information on a building from all its construction phases and can solve problems such as data loss, input information, and overlaps. Eventually, it can manage all information effectively. 
To efficiently manage all kinds of construction information, related guidelines and standards must be developed. This study is a basic research to develop quantity-takeoff guidelines.

Table 1. Definitions of BIM in different organizations.

\begin{tabular}{|c|c|}
\hline Organization & Definition \\
\hline AIA & $\begin{array}{l}\text { A model-based technology related to the project } \\
\text { information DB (linked to regional, national and } \\
\text { international standards such as specifications) }\end{array}$ \\
\hline \multirow[t]{2}{*}{ ArchiCAD } & $\begin{array}{l}\text { A storage medium that contains graphic and non- } \\
\text { graphic documents (specifications, schedules, and extra } \\
\text { documents) }\end{array}$ \\
\hline & $\begin{array}{l}\text { Creates consistent and concurrent information on } \\
\text { building projects }\end{array}$ \\
\hline Autodesk & $\begin{array}{l}\text { The created information is used in operations } \\
\text { management, design decision-making, high-quality } \\
\text { construction document production, performance } \\
\text { prediction, cost prediction, and construction planning. }\end{array}$ \\
\hline Bentley & $\begin{array}{l}\text { Life cycle graphic and non-graphic modeling for } \\
\text { effective outcomes }\end{array}$ \\
\hline GSA & $\begin{array}{l}\text { Computer software data model that was developed to } \\
\text { document building designs and manage new social } \\
\text { capital }\end{array}$ \\
\hline NIBS & $\begin{array}{l}\text { Expresses life cycle information such as physical and } \\
\text { functional characteristics to show better values }\end{array}$ \\
\hline
\end{tabular}

\section{b) BIM Tools}

(1) Revit Architecture

Revit in Autodesk defines BIM as a model that contains all building information and as a well-known software. Revit has the advantage of being easy to learn, having well-designed functions and a user-friendly interface, and as offering the following specialized solutions.

- Revit Architecture: design and architecture modeling

- Revit Structure: structural modeling and integration of structural software

- Revit MEP: mechanical, electrical and plumbing modeling and energy interpretation

\section{(2) Bentley Architecture}

Bentley Architecture in Bentley is based on the Microstation CAD Platform and is an effective productivity tool in 3D CAD, especially in freeform design. It has advantages in quantity takeoff, 2D design abstracting, and constructability, but it has the disadvantage of a user-unfriendly interface. It is used widely in the United States.

\section{(3) ArchiCAD}

ArchiCAD in Graphisoft is an object-oriented architectural CAD system that models cyberspace through visualization. It can also interpret energy, has an interface for sustainability, and uses the Geometric Description Language (GDL). Graphisoft recently developed the EMP technology in cyberspace building storage based on the IFC model server, which is expected to be one of the most advanced technologies in the move to the future BIM.

All these BIM tools are suitable for building design and quantitytakeoff, and provide similar results in similar situations. ArchiCAD is used in this study for quantity-take-off. c) Quantity Take-off Using Commercial BIM Tools

Revit, Bentley Architecture and ArchiCAD, which can be called the most typical of the domestic and foreign commercialized BIM tools, have different defining methods and property construction methods for the object that is modeled with each tool (Eastman et al., 2008). The concept of quantity estimation as property information is mapped to the object created through the modeling, however, whereas the quantity is estimated with the volume, area, and length of the created object.

Because the quantity take-off using BIM is object-oriented, it is significantly influenced by the modeling method. Therefore, guidelines on the 3D based modeling method are needed to verify the method and for accurate quantity take-off.

\section{2) Reinforced Concrete Estimation}

a) Reinforced Concrete Estimation Standards

The quantity of reinforced concrete is estimated after it is classified into concrete, a form, or a rebar (Kim et al., 2002). Therefore, while the quantity of reinforced concrete is so estimated (Choi et al., 2006), in this study, only the quantities of concrete and forms are estimated, and not those of rebars, because rebars cannot be generalized due to the complexity of their assembly. The reinforced concrete estimation standard described in this study applies the general quantity take-off standard of South Korea.

\section{b) BIM Design Guidelines from Virtual Construction}

BIM Application to Design Guidelines from the Virtual construction system develop research group (2010) documents U.S. and Northern European best practices jointly with relevant organizations and companies and announced the industry-targeted guidelines. Such document provides the preliminary guidelines for introducing and applying BIM in all areas of architecture such as order, architecture, structure, engineering, construction, civil works, and landscaping, and in all phases of architecture, from the pre-design to the post-construction.

\section{ANALYSIS OF THE BIM OTO TECHNIOUUE}

\section{1) Quantity Take-Off (QTO)}

a) Automatic QTO from the General BIM Model

This model has completed the object shown in Figure 1 according to the most widely performed method. The quantities modeled in this manner are shown in Table 2.

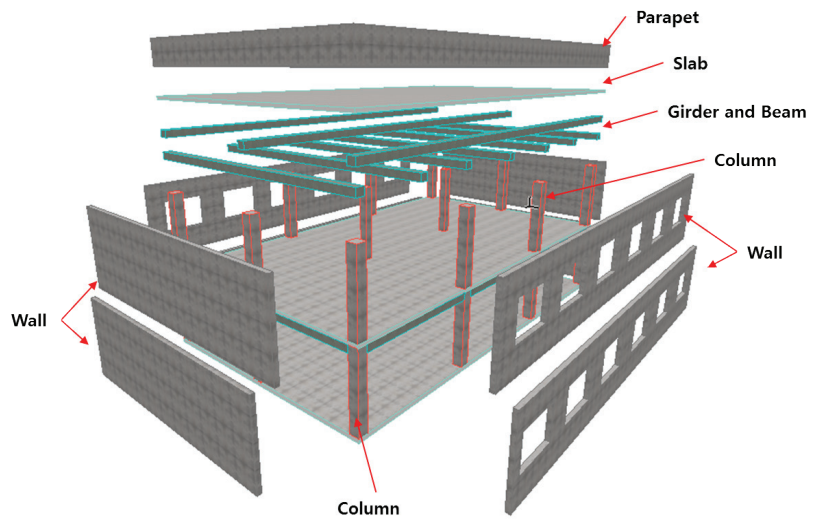

Figure 1. General BIM modeling. 
Table 2. Quantities from the general BIM model.

\begin{tabular}{llr}
\hline Location & Work & Quantity \\
\hline \multirow{2}{*}{ Column } & Form $\left(\mathrm{m}^{2}\right)$ & 174.00 \\
& Concrete $\left(\mathrm{m}^{3}\right)$ & 21.20 \\
Wall & Form $\left(\mathrm{m}^{2}\right)$ & 909.26 \\
& Concrete $\left(\mathrm{m}^{3}\right)$ & 86.72 \\
\multirow{2}{*}{ Girder } & Form $\left(\mathrm{m}^{2}\right)$ & 193.80 \\
& Concrete $\left(\mathrm{m}^{3}\right)$ & 30.23 \\
Slab & Form $\left(\mathrm{m}^{2}\right)$ & 806.25 \\
& Concrete $\left(\mathrm{m}^{3}\right)$ & 134.37 \\
Sum & Form $\left(\mathrm{m}^{2}\right)$ & $2,083.31$ \\
& Concrete $\left(\mathrm{m}^{3}\right)$ & 272.52 \\
\hline
\end{tabular}

b) QTO from the Commercial Estimation Software

The virtual facility shown in Figure 2 is a building with a length of $21.5 \mathrm{~m}$, a width of $12.5 \mathrm{~m}$, and a total floor area of $537 \mathrm{~m} 2$. The floor plan of this facility is shown in Figure 2.

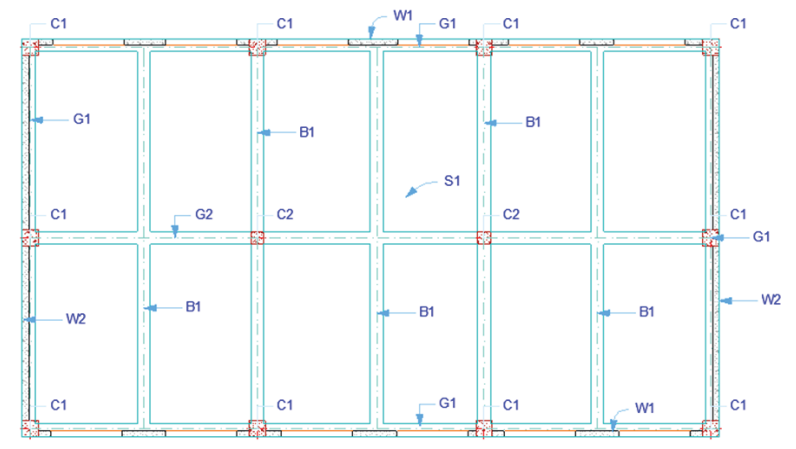

Figure 2. Floor plan of the virtual facility.

As a result of the estimation of the quantity by a quantity surveyor using a commercial estimation software, the form and concrete quantity of the column in the virtual facility were totaled as $174 \mathrm{~m} 2$ and $21.15 \mathrm{~m} 3$, respectively; the form and concrete quantity of the wall, as $865.1 \mathrm{~m} 2$ and $70.24 \mathrm{~m} 3$; the form and concrete quantity of the girder, as $180.18 \mathrm{~m} 2$ and $27.148 \mathrm{~m} 3$; and the form and concrete quantity of the slab, $765.93 \mathrm{~m} 2$ and $127.656 \mathrm{~m} 3$.

Table 3. Quantities from the commercial estimation software.

\begin{tabular}{llr}
\hline Location & Work & Quantity \\
\hline \multirow{2}{*}{ Column } & Form $\left(\mathrm{m}^{2}\right)$ & 174.00 \\
& Concrete $\left(\mathrm{m}^{3}\right)$ & 21.15 \\
Wall & Form $\left(\mathrm{m}^{2}\right)$ & 865.10 \\
& Concrete $\left(\mathrm{m}^{3}\right)$ & 70.24 \\
Girder & Form $\left(\mathrm{m}^{2}\right)$ & 180.18 \\
& Concrete $\left(\mathrm{m}^{3}\right)$ & 27.15 \\
Slab & Form $\left(\mathrm{m}^{2}\right)$ & 765.93 \\
& Concrete $\left(\mathrm{m}^{3}\right)$ & 127.66 \\
Sum & Form $\left(\mathrm{m}^{2}\right)$ & $1,985.21$ \\
& Concrete $\left(\mathrm{m}^{3}\right)$ & 246.19 \\
\hline
\end{tabular}

c) Problem from Comparison of the QTOs

The two types of estimated quantity data were compared by element for use as the basic data for the BIM modeling guidelines.

The comparison of the two types of quantity data showed a difference between the concrete quantity and the form quantity. Thus, the estimated quantity differed according to the program priority even if the modeling tool had a quantity exemption standard, because BIM is characteristically object-oriented.

Table 4. Comparison of the two types of quantity data.

\begin{tabular}{llcr}
\hline Location & Work & Estimation Software & BIM Model \\
\hline \multirow{2}{*}{ Column } & Form $\left(\mathrm{m}^{2}\right)$ & 174.00 & 174.00 \\
& Concrete $\left(\mathrm{m}^{3}\right)$ & 21.15 & 21.20 \\
\multirow{2}{*}{ Wall } & Form $\left(\mathrm{m}^{2}\right)$ & 865.10 & 909.26 \\
& Concrete $\left(\mathrm{m}^{3}\right)$ & 70.24 & 86.72 \\
\multirow{2}{*}{ Girder } & Form $\left(\mathrm{m}^{2}\right)$ & 180.18 & 193.80 \\
& Concrete $\left(\mathrm{m}^{3}\right)$ & 27.15 & 30.23 \\
\multirow{2}{*}{ Slab } & Form $\left(\mathrm{m}^{2}\right)$ & 765.93 & 806.25 \\
& Concrete $\left(\mathrm{m}^{3}\right)$ & 127.66 & 134.37 \\
\multirow{2}{*}{ Sum } & Form $\left(\mathrm{m}^{2}\right)$ & 1985.21 & $2,083.31$ \\
& Concrete $\left(\mathrm{m}^{3}\right)$ & 246.19 & 272.52 \\
\hline
\end{tabular}

Therefore, all the elements must be individualized to more accurately estimate the quantity. The efficiency can only be considerably lowered in the BIM modeling task, however, due to the required time if the modeling is performed by element, as in the aforementioned manner. The modeling technique must also have performed accurate QTO and efficient modeling.

\section{2) Automatic QTO from the Modeling by Element}

If the modeling was completed before the analysis of the modeling methods by element, the assumption on overlaps and connections has been minimized to minimize the modeling error.

\section{a) Foundation}

As the foundation work is performed before all other works in the modeling of structures, without interference and restrictions from other elements, it has few errors and involves relatively simple performance of the QTO and modeling. Accordingly, the general modeling method is used to model the foundation.

\section{b) Column}

The most important element of the modeling of columns is the $Z$ value, or in other words, the setting of the height. The individual quantity of the column may be estimated as differing according to the set height, and the quantity of the element connected to the column may be estimated as different. There are two types of column modeling: Alt 1, in which the distance from the upper slab of the corresponding floor to the upper slab of the next floor is modeled, and Alt 2, in which the distance from the upper slab of the corresponding floor to the lower slab of the next floor is modeled. 


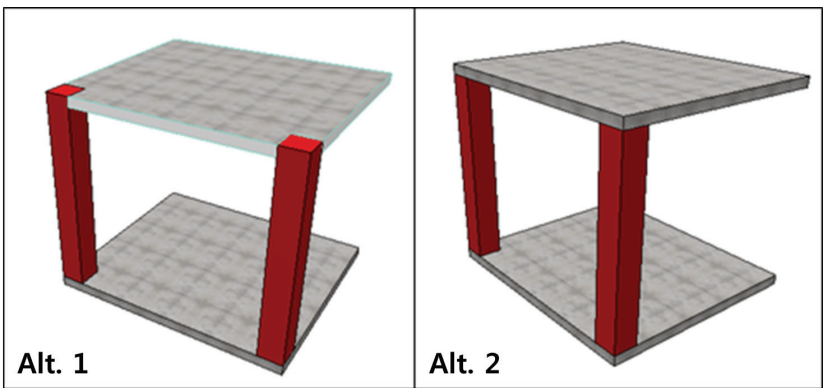

Figure 3. Column modeling.

In Alt 1, although the modeling error with respect to the height of the column can be reduced because the total height of the corresponding floor is estimated with the column height, the slab modeling is affected because the modeling must be performed without the column element for the modeling of the slab of the next floor.

To model the column with Alt 2, despite the difficulty of excluding the slab thickness, the efficiency can be further raised while modeling the slab of the next floor in the future.

The comparison of the two types of modeling methods with automatic QTO showed that the modeling method of Alt 2 yields the same value as the commercial estimation software.

The difference between Alt 1 and 2 and the real quantity is 0.01 , which might have been due to the rounding off in the quantity calculation.

Table 5. Comparison of Alt 1 and 2 for the column.

\begin{tabular}{lccccl}
\hline \multirow{2}{*}{ Method } & \multicolumn{2}{c}{ Concrete $\left(\mathrm{m}^{3}\right)$} & \multicolumn{2}{c}{ Form $\left(\mathrm{m}^{3}\right)$} & Note \\
\cline { 2 - 5 } & $\mathrm{Col}^{*}$ & Slab & Col $^{*}$ & Slab & \\
\hline Alt 1 & 2.0 & 4.35 & 16.0 & 21.77 & $\begin{array}{l}\text { Low } \\
\text { efficiency }\end{array}$ \\
Alt 2 & 1.9 & 4.35 & 15.2 & 21.77 & $\begin{array}{l}\text { High } \\
\text { efficiency }\end{array}$ \\
$\begin{array}{l}\text { Real } \\
\text { Quantity }\end{array}$ & 1.9 & 4.35 & 15.2 & 21.76 & \\
\hline
\end{tabular}

${ }^{*} \mathrm{Col}=$ Column

\section{c) Girder}

The modeling of the girder significantly affects the element connected to the girder, the modeling method, and the quantity of the modeled slab, depending on how the height of the girder is estimated; and the length of the girder affects the modeling and quantity of the column.

There are two modeling methods according to the girder height: Alt 1 , the method of modeling the remaining part, except for the slab thickness, among the height of the girder with the height of girder; and Alt 2, the method of modeling the total height of the girder.

Although Alt 1 is the same as the method of modeling the concrete quantity, they differ in their form quantity. Alt 1 was shown as effective, however, in terms of its modeling efficiency.

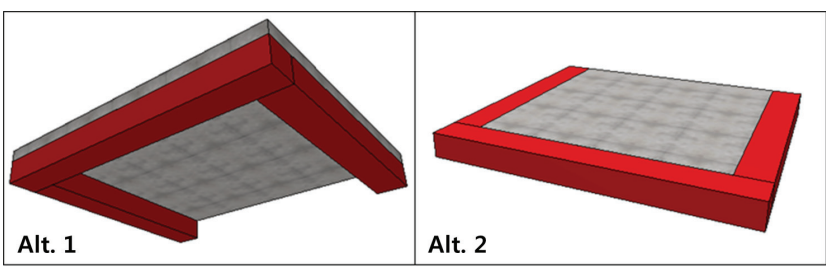

Figure 4. Girder modeling with a slab.

Table 6. Comparison of Alt 1 and 2 for girder modeling.

\begin{tabular}{lccccl}
\hline \multirow{2}{*}{ Method } & \multicolumn{2}{l}{ Concrete $\left(\mathrm{m}^{3}\right)$} & \multicolumn{2}{c}{ Form $\left(\mathrm{m}^{3}\right)$} & Note \\
\cline { 2 - 5 } & Girder & Slab & Girder & Slab & \\
Alt 1 & 2.55 & 4.35 & 16.58 & 21.77 & $\begin{array}{l}\text { Form quantity } \\
\text { error between two } \\
\text { girders }\end{array}$ \\
Alt 2 & 3.05 & 4.85 & 16.92 & 22.01 & $\begin{array}{l}\text { Low slab efficiency } \\
\text { Possible modeling } \\
\text { error }\end{array}$ \\
$\begin{array}{l}\text { Real } \\
\text { Quantity }\end{array}$ & 2.55 & 4.35 & 17.1 & 21.26 & \\
\hline
\end{tabular}

There are two types of modeling method according to the girder length: Alt 1, the method of modeling the girder between the columns on both sides; and Alt 2, the method of modeling the girder with the center line between the columns on both sides

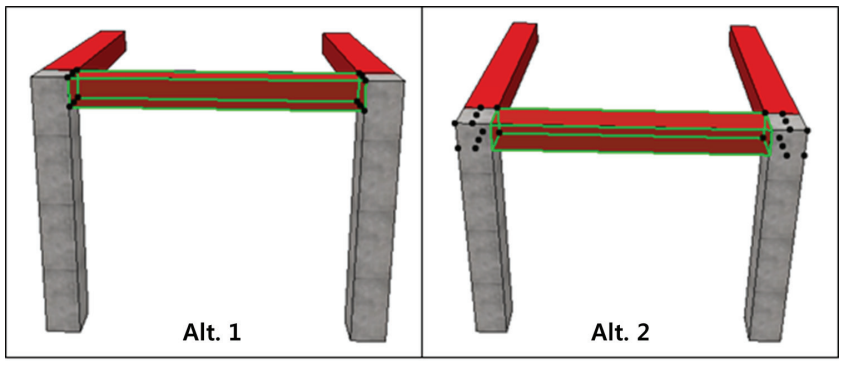

Figure 5. Modeling of the girder between the columns.

Alt 2 was shown as effective in terms of its modeling efficiency.

Table 7. Comparison of 1 and 2 for girder modeling.

\begin{tabular}{lccccl}
\hline \multirow{2}{*}{ Method } & \multicolumn{2}{c}{ Concrete $\left(\mathrm{m}^{3}\right)$} & \multicolumn{2}{c}{ Form $\left(\mathrm{m}^{3}\right)$} & Note \\
\cline { 2 - 5 } & Girder & Slab & Girder & Slab & \\
Alt 1 & 2.35 & 1.90 & 15.28 & 15.2 & $\begin{array}{l}\text { Low } \\
\text { efficiency }\end{array}$ \\
Alt 2 & 2.35 & 1.90 & 15.28 & 15.2 & $\begin{array}{l}\text { Possible } \\
\text { modeling } \\
\text { error }\end{array}$ \\
$\begin{array}{l}\text { Real } \\
\text { Quantity }\end{array}$ & 2.36 & 1.9 & 15.82 & 15.2 & \\
\hline
\end{tabular}

\section{d) Slab}

Slab modeling methods differ in their automatic QTO and modeling efficiency, depending on the modeling method for the column and the girder, whereas slab modeling is determined by the modeling of the column and the girder. 
e) Wall

Wall modeling significantly affects the elements connected to the wall. The modeling of the girder, slab, and column may vary depending on the definition of the height and length of the wall for accurate modeling, and accordingly, significantly affects the automatic quantity estimation. Therefore, wall modeling must be performed without much influence on the girder, slab, and column. There are two types of wall modeling: Alt 1, the method of modeling both the height and the length of a wall as the inside bottom dimensions of the lower column, the slab, and the girder; and Alt 2, the method of modeling by setting the height of the wall as the bottom of the upper slab and the length as the entire wall. The area of the column and the girder must be reduced in Alt 2, though.

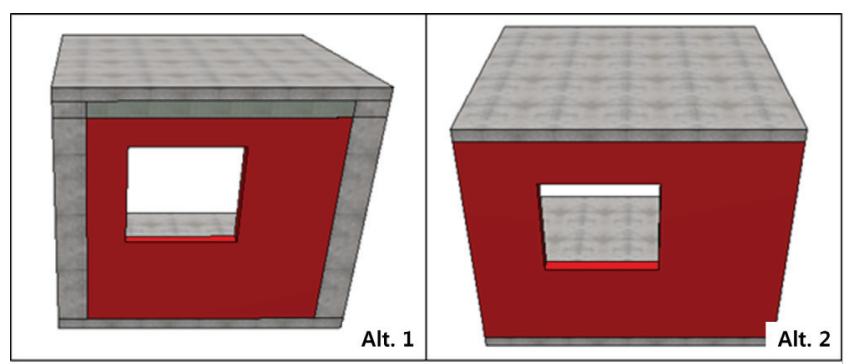

Figure 6. Modeling on the wall.

In wall modeling using Alt 1, the modeling efficiency is lowered. Accurate QTO on the object becomes possible, though.

In wall modeling using Alt 2, the change in the column and the girder becomes unavoidable, though the modeling efficiency improves.

Table 8. Comparison of Alt 1 and 2 for wall modeling.

\begin{tabular}{lllll}
\hline Method & \multicolumn{2}{l}{ Concrete $\left(\mathrm{m}^{3}\right)$} & & Note \\
& Wall & Column & Girder & \\
Alt 1 & 2.21 & 1.9 & 1.47 & Low efficiency \\
Alt 2 & 2.92 & 1.14 & 1.27 & Modeling error \\
Real Quantity & 2.19 & 1.9 & 1.5 & \\
\hline Method & Form $\left(\mathrm{m}^{2}\right)$ & & & Note \\
\cline { 2 - 5 } & Wall & Column & Girder & \\
\hline Prop 1 & 11.07 & 15.2 & 11.76 & Low efficiency \\
Prop 2 & 14.62 & 12.16 & 10.98 & Modeling error \\
Software & 10.24 & 15.2 & 12.5 & \\
\hline
\end{tabular}

f) Difference between the traditional method and the modeling method

When reinforced concrete is estimated using the traditional method, the volume and area must be divided; but in BIM modeling, those units cannot be divided. Therefore, QTO data form modeling is required to minimize the error.

In this study, the form data had more problems than the concrete data in considering the error rate from the BIM modeling. The difference between the traditional method and the modeling method is shown in Table 9.
Table 9. Difference between the two methods.

\begin{tabular}{|c|c|c|c|c|}
\hline & \multicolumn{2}{|c|}{ Traditional Method } & \multicolumn{2}{|c|}{ BIM Modeling } \\
\hline & Length & Height & Length & Height \\
\hline $\begin{array}{l}\text { Foun- } \\
\text { dation }\end{array}$ & \multicolumn{2}{|c|}{ Under the first slab } & \multicolumn{2}{|c|}{ Under the first slab } \\
\hline Column & Column & Between slabs & Column & $\begin{array}{l}\text { Between } \\
\text { slabs }\end{array}$ \\
\hline Girder & $\begin{array}{c}\text { Inter- } \\
\text { dimension }\end{array}$ & $\begin{array}{l}\text { Excluding the } \\
\text { slab }\end{array}$ & $\begin{array}{c}\text { Center } \\
\text { dimension }\end{array}$ & $\begin{array}{l}\text { Excluding } \\
\text { the slab }\end{array}$ \\
\hline Slab & $\begin{array}{l}\text { Between } \\
\text { walls }\end{array}$ & Slab height & Slab length & Slab height \\
\hline Wall & $\begin{array}{c}\text { Inter- } \\
\text { dimension }\end{array}$ & Between slabs & $\begin{array}{c}\text { Inter- } \\
\text { dimension }\end{array}$ & $\begin{array}{l}\text { Under the } \\
\text { girder }\end{array}$ \\
\hline
\end{tabular}

\section{BIM MODELING GUIDELINES IN OTTO}

The guidelines for the framework modeling by element have been presented based on Section 3.2 (Automatic QTO According to the Modeling by Element).

\section{1) Foundation}

The foundation is modeled with the design measurements, with the ground line (G.L) as the boundary, and with the basement floor as the boundary if there is a basement.

\section{2) Column}

The column is modeled with the design measurements, from the column base to the lower slab if there is a column on the lowest floor, and is modeled using the distance from the upper slab of the corresponding floor to the lower slab of the upper floor as the design measurement at the base floor.
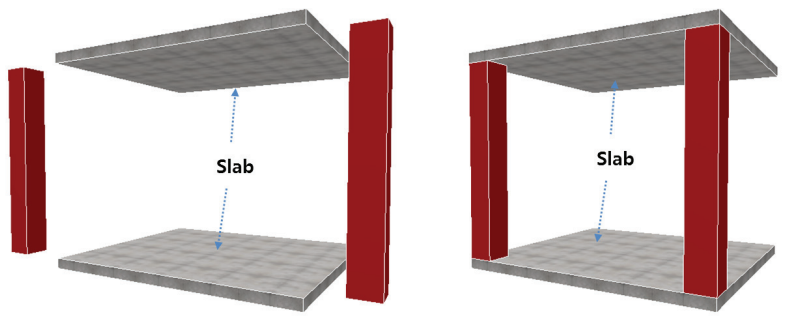

Figure 7. Column modeling guidelines.

\section{3) Girder}

The girder is modeled by setting the part that excludes the slab thickness, among the girder heights, as the height of the girder, objectifying the distance between the center lines of the column as the length of the girder, and objectifying the length of a small girder as the distance between the center lines of a large girder.
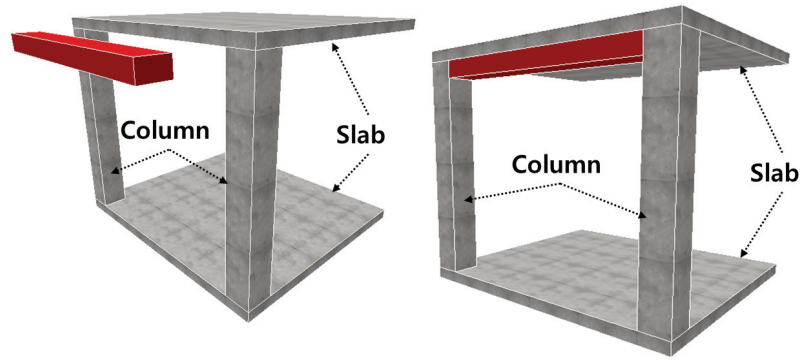

Figure 8. Girder modeling guidelines. 
4) Slab

The slab is modeled by objectifying the design thickness of the slab to the entire area of the floor board (the area surrounded by the floor contour line) and by recognizing the part that overlaps with the girder as the slab object.
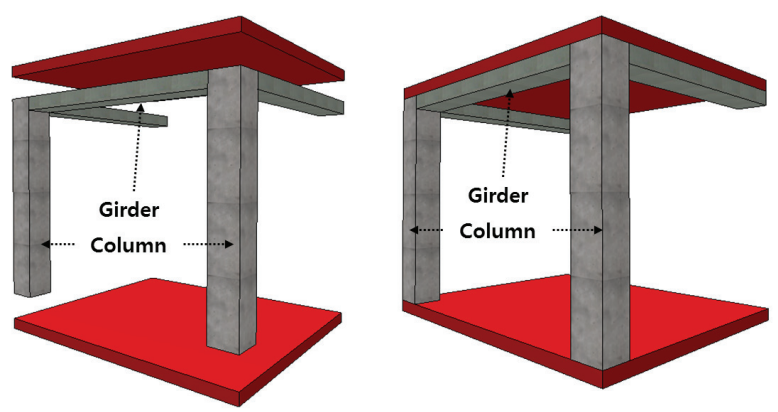

Figure 9. Slab modeling guidelines.

5) Wall

The wall is modeled by setting the inside distance between the columns as the length of the wall and using the height from the upper slab of the corresponding floor to the bottom of the upper floor girder.
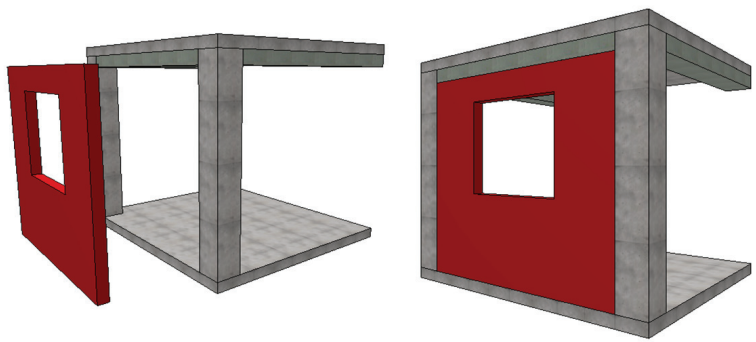

Figure 10. Wall modeling guidelines.

\section{CASE STUDY IN A VIRTUAL FACILITY}

The modeling was completed as shown in Figure 11, after it was applied to a virtual facility using the guidelines presented in this study. The traditional modeling requires much more time than the general BIM modeling. This is because the traditional modeling is performed by assigning object information to each element. The quantity estimation and totalization by element are deemed to become easier in the future because the modeling must be performed by element.

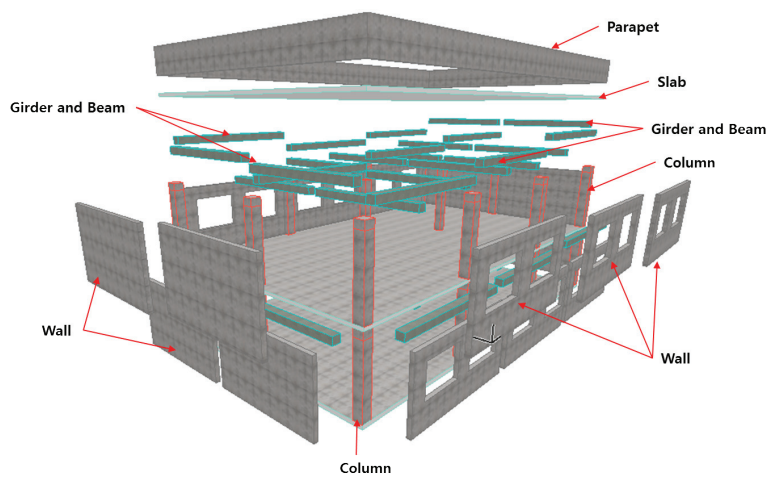

Figure 11. Model produced based on the modeling guidelines
Table 10 shows the comparison and analysis values using the quantity from the commercial estimation software through the reinforced concrete estimation standards for the virtual facility and the modeling guidelines for the structure presented in this study.

Table 10. Comparison of the commercial estimation software guidelines and the proposed modeling guidelines.

\begin{tabular}{llrrr}
\hline Item & & & & Quantity \\
\hline Loca-tion & Work & Software & $\begin{array}{r}\text { Proposed } \\
\text { Model }\end{array}$ & Gap \\
\hline \multirow{2}{*}{ Co-lumn } & Form $\left(\mathrm{m}^{2}\right)$ & 174.000 & 174.00 & - \\
& Concrete $\left(\mathrm{m}^{3}\right)$ & 21.150 & 21.20 & \\
& Form $(\mathrm{m} 2)$ & 865.100 & 823.84 & 41.260 \\
Wall & Concrete $\left(\mathrm{m}^{3}\right)$ & 70.236 & 72.16 & -1.924 \\
& Form $\left(\mathrm{m}^{2}\right)$ & 180.180 & 191.56 & -11.380 \\
Girder & Concrete $\left(\mathrm{m}^{3}\right)$ & 27.148 & 30.32 & -3.172 \\
& Form $\left(\mathrm{m}^{2}\right)$ & 765.930 & 806.25 & -40.320 \\
Slab & Concrete $\left(\mathrm{m}^{3}\right)$ & 127.656 & 130.37 & -2.714 \\
& Form $\left(\mathrm{m}^{2}\right)$ & $1,985.210$ & $1,995.65$ & -10.440 \\
& Concrete $\left(\mathrm{m}^{3}\right)$ & 246.190 & 254.05 & -7.810 \\
\hline
\end{tabular}

The comparison of the two types of QTO yielded the following result. The estimation of the automatic quantity based on the modeling, with a $0.53 \%$ estimated quantity error for the form using the commercial estimation software and $3.17 \%$ for the concrete quantity, verified that the modeling guidelines presented in this study are very accurate in terms of the QTO.

\section{CONCLUSION}

This study was conducted to enhance the accuracy and practical applicability of modeling in construction, which is performed by different persons with different methods, by proposing clear BIM modeling standards based on QTO automation. Modeling by element is necessary for accurate automatic QTO using the BIM model, and the following results were attained after the presentation of the developed modeling guidelines by element.

The limitations and problems of the existing modeling technique were identified by comparing the data from the general BIM modeling technique with the data from the use by a quantity surveyor of a commercial estimation software.

Second, the automatic QTO were derived using different modeling methods by element to enhance the accuracy of the QTO using BIM with the modeling guidelines by element with the lowest error margin.

Third, the usability and accuracy of the reinforced structure modeling guidelines were verified by comparing the quantity from the commercial estimation software with the modeling quantity using the proposed modeling guidelines.

This study showed the need for further studies on the rebar quantity and on finishing work modeling guidelines, beyond those for the framework. 


\section{REFERENCES}

Choi, C., (2008), BIM for future construction technology and Strategic Plan, Special Issue, Korea Institute of Construction Engineering and Management, 9-14

Choi, S, Oh, J., and Lim, N., (2006) Estimation in architecture, Kimmoondang, Seoul

Eastman, C., Teicholz, P., Rafael, S., and Liston, K., (2008) BIM Handbook: A Guide to Building Information Modeling for Owners, Managers, Designers, Engineers, and Contractors, Wiley

Gu, N. and London, K., (2010) "Understanding and facilitating BIM adoption in the AEC industry" Automation in Construction, 19, 8

Kim, J., and Choi, D., (2002) Estimation for estimator, Kumiseogwan, Seoul

Lee, M. C., (2010) A Study on the BIM Property Information Modeling for the Cost Estimate of the Public Construction Projects, Master Thesis, Graduate School of Housing, Seoul National University of Science and Technology

Virtual Construction System Develop Research Group (2010), BIM Application to Design Guidelines Volume 1(Version 2.0), Virtual Construction System Develop Research Group

(Received September 25, 2012/Accepted November 5, 2012) 